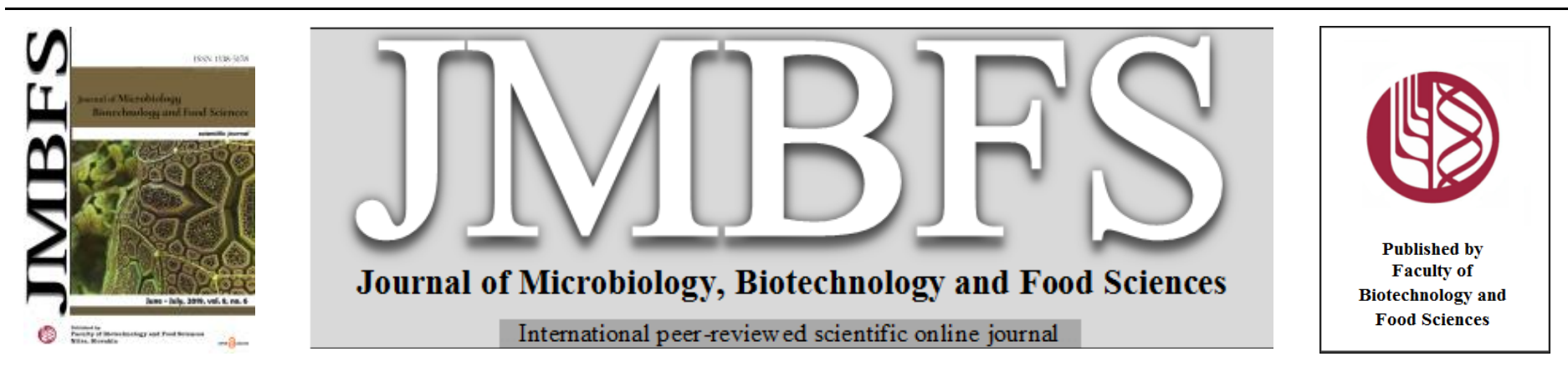

\title{
BIOFILM FORMATION BY Aquaspirillum spp. AND SAPROPHYTIC Leptospira spp. ISOLATED FROM ENVIRONMENTAL SOURCE OF ARGENTINE
}

\author{
$\operatorname{Address(es):~}$ \\ ${ }^{1}$ División Zoonosis Rurales, España 770, Azul (7300), Provincia de Buenos Aires, Argentina. \\ ${ }^{2}$ Instituto de Patobiología, CCVyA-CNIA, INTA. CC 77 (1708) Morón, Provincia de Buenos Aires, Argentina. \\ ${ }^{3}$ UNCPBA, Fac. Agronomía, Azul, Provincia de Buenos Aires, Argentina. \\ ${ }^{4}$ National Research Council of Argentina (CONICET), Buenos Aires, Argentina. \\ ${ }^{5}$ Instituto de Análisis Fares Taie, Rivadavia 3331 (7600), Mar del Plata, Provincia de Buenos Aires, Argentina. \\ ${ }^{6}$ Comisión de Investigaciones Científicas (CIC) de la Provincia de Buenos Aires, Argentina.
}

Scialfa Exequiel ${ }^{* 1,3}$; Videla Yanina, ${ }^{1,6}$; Grune Loffler Sylvia ${ }^{2,4}$; Quintana Silvina ${ }^{5}$; Aguirre Pablo and Brihuega Bibiana $^{2}$

*Corresponding author: escialfa@ yahoo.com.ar

doi: $10.15414 / j m b f s .2019 .8 .6 .1265-1270$

\section{ARTICLE INFO}

Received 9. 3. 2018

Revised 16. 1. 2019

Accepted 29. 1. 2019

Published 1. 6. 2019

Regular article

open 2 access

\begin{abstract}
Leptospirosis is a zoonotic disease of global distribution, caused by bacteria of the genus Leptospira. These spirochetes are living organisms free of mud and water; pathogenic leptospires can survive several days in fresh water when $\mathrm{pH}$ and temperature are adequate. During 2016, water samples were collected from Callvú Leovú stream (Azul, Buenos Aires); samples were inoculated in liquid EMJH medium and incubated at $28^{\circ} \mathrm{C}$ for 90 days. Six isolates of saprophytic leptospires and six of spirils (Aquaspirillum spp.) were obtained. The isolates were inoculated in EMJH (liquid and semi-solid) medium and sterile stream water at $4-10^{\circ} \mathrm{C}$ and $28-30^{\circ} \mathrm{C}$; development was observed periodically using dark field microscopy. Both bacteria (alone or together) grew exponentially in first three weeks in all media incubated at $28-30^{\circ} \mathrm{C}$; the semi-solid medium was the most efficient at $28-30^{\circ} \mathrm{C}$ of incubation, and the bacteria remained viable after 16 weeks. At $4-8^{\circ} \mathrm{C}$ both bacteria remained undetectable but viable in media incubated at $4-8^{\circ} \mathrm{C}$ for three weeks until the temperature was optimal (thermal stimulation). Leptospires developed in all media used and remained viable for 112 to 168 days (at 4 $8^{\circ} \mathrm{C}$ incubation) in liquid media. The formation of cellular aggregate between Leptospira spp. and Aquaspirillum spp. was independent at the incubation temperature. These results suggest that Aquaspirillum spp. coexists with the genus Leptospira in surface waters, and their presence may indicate possible circulation of leptospires.
\end{abstract}

Keywords: Leptospira spp., Aquaspirillum spp., biofilm, cell aggregation

\section{INTRODUCTION}

Depending on the shape of bacteria, they are classified as cocci (spherical or oval cells), bacilli (rod shaped cells), vibrios (comma shaped curved rods), spirilla (rigid spiral forms), spirochetes (flexible spiral forms), actinomycetes (branching filamentous forms) and mycoplasmas (cell wall deficient forms). Helical bacteria have been found in nature under very diverse circumstances, and spirochetes (Treponema spp., Borrelia spp. and Leptospira spp.) are free-living inhabitants of mud and water.

All Aquaspirillum species described in Bergey's Manual of Systematic Bacteriology share the following characteristics: they are all rigid helical cells, except for Aquaspirillum delicatum which is vibrio and Aquaspirillum fasciculus which is a straight rod. The genus Aquaspirillum, with 13 species, was created for all aerobic freshwater spirilla having a low salt tolerance (Pot, 2006) Leptospires are aerobic spirochetes whose cells are flexuous, motile, tightly coiled and have axial flagella; they are gram negative and there is no visua difference between serogroups. Some are pathogenic, though others are harmless freshwater saprophytes; all requiring oxygen (dissolved in water) to survive. The genus Leptospira sp. includes at least 22 species arranged into three large subgroups based on 16S rRNA phylogeny, ten (10) pathogenic species, seven (7) saprophytic species and five (5) intermediate species (Bourhy et al., 2014; Picardeau, 2017). Saprophytic Leptospira spp. is free-living environmental microorganisms; however, pathogens leptospires can survive several days in fresh water when $\mathrm{pH}$ and temperature are adequate (Faine $\boldsymbol{e t}$ al., 1999; Trueba et al., 2002). Each bacterium grows and divides independently of any other bacteria, although aggregates of bacteria (biofilms) have been frequently observed, even with members of different species (Ristow et al., 2008). Biofilm formation has been observed between saprophytic and pathogenic leptospires, Azospirillum brasiliensis and pathogenic leptospires, and between Sphingomonas sp. whit Leptospira spp. (Barragan et al., 2011; Kumar et al., 2015; Ristow et al., 2008). These cellular aggregates would give them protection from dynamic environments and even survive in poor nutrient conditions. In other studies, the ability to form bacterial aggregations in vivo was observed in pregnant guinea pigs infected with Leptospira Pomona (Brihuega et al., 2012).

The present research shows the behaviour and growth of Leptospira spp. and Aquaspirillum spp. in aqueous and semi-solid fluid (with and without nutrients) incubated at different temperatures, such as the interaction and biofilm-forming of leptospires with environmental bacteria.

\section{MATERIAL AND METHODS}

Study area

The stream Callvú Leovú is born in the vicinity of the town of Chillar, Buenos Aires province; and after traveling about $60 \mathrm{~km}$ crosses the city of Azul to end at Canal 11 (city of Las Flores), the mentioned channel was built in order to drain the waters of this channel and of other streams towards the Samborombón Bay.

\section{Sample collection and culture}

Water samples were collected from Callvú Leovú stream during 2016 years and transported in sterile 500 millilitres glass bottles (Figure 1). Temperature and $\mathrm{pH}$ were monitored in the field. Water samples were filtered through a sterile membrane. In this study, a pre-filter technique was applied using Whatman filter paper before filtration through membrane filter with $0.22 \mu \mathrm{m}$ pore size. All samples were collected in early morning. A sample of the filtered water (one millilitre) was inoculated into Ellinghausen-McCullough-Johnson-Harris (EMJH medium: Difco Laboratories, Detroit Michigan USA) liquid medium without the addition 5-fluorouracil as selective antimicrobial agent. Cultures were incubated by duplicate at $13^{\circ} \mathrm{C}$ and $28-30^{\circ} \mathrm{C}$ during 90 days, and bacterial 
(Aquaspirillum spp. and Leptospira spp.) growth was monitored weekly using dark field microscopy. If leptospires or spirilla were not detectable after 90 days of incubation, the sample was considered to be negative.

\section{Production of pure cultures}

To obtain pure cultures of leptospires and Aquaspirillum spp., liquid and semisolid media of EMJH and Thyoglicollate (pure and mixed) with and without addition of 5-fluorouracil $(300 \mu \mathrm{m} / \mathrm{ml})$ were used, in all cases the $\mathrm{pH}$ was 7.2 .

\section{Characterization of Leptospiral isolates}

Multiple Locus Variable number tandems repeat Analysis (MLVA) genotyping

Faine DNA templates were obtained using Chelex Resin-100 (Bio Rad). MLVA was performed using two sets of oligonucleotides specific for pathogenic leptospires (L. interrogans, L. kirschneri and L. borgpetersenii). Oligonucleotides that hybridized to the flanking regions of the VNTR4, VNTR7, VNTR9, VNTR10, VNTR19, VNTR23 and VNTR31 loci were used to discriminate strains of $L$. interrogans and oligonucleotides that hybridized to the flanking regions of the VNTR4, VNTR7, VNTR10, Lb4 and Lb5 loci were used for $L$. kirschneri, L. borgpetersenii and L. interrogans strains (Majed et al. 2005; Pavan et al. 2011). The final volume $(50 \mu \mathrm{l})$ of each reaction mixture contained polymerase chain reaction (PCR) buffer (20 mM Tris- $\mathrm{HCl}, \mathrm{pH} 8.4,50 \mathrm{mM}$ $\mathrm{KCL}), 200 \mu \mathrm{M}$ deoxynucleoside triphosphates, $2 \mu \mathrm{M}$ each of the corresponding forward and reverse primers, $2 \mathrm{mM} \mathrm{MgCl}, 1.25 \mathrm{U}$ of Taq DNA polymerase (Invitrogen) and $5 \mu \mathrm{l}$ of DNA template. PCR amplifications were carried out in a Thermo Scientific PxE 0.2 Thermal Cycler, using the following cycling parameters: $94^{\circ} \mathrm{C}$ for $5 \mathrm{~min}$, followed by 35 cycles of denaturalization at $94^{\circ} \mathrm{C}$ for $30 \mathrm{~s}$, annealing at $55^{\circ} \mathrm{C}$ for $30 \mathrm{~s}$ and extension at $72^{\circ} \mathrm{C}$ for $90 \mathrm{~s}$, with a final cycle at $72^{\circ} \mathrm{C}$ for $10 \mathrm{~min}$. The amplified samples were examined by electrophoresis in ethidium bromide-containing $2 \%$ agarose gels in TAE buffer (40 mM Tris-acetate, $1 \mathrm{mM}$ EDTA, $\mathrm{pH} 8.0$ ) at $100 \mathrm{~V}$ for $50 \mathrm{~min}$. Amplified DNA bands were visualized through ultraviolet light exposure (Uvi Tec transiluminator BTS-20.M, Manufacturer UviTec, St. John's Innovation Centre, Cowley Road, Cambridge, England). Amplicon sizes were estimated using CienMarker (Biodynamics) and the GelAnalyzer 2010a program. To calculate repeat copy numbers, the following formula was used: number of repeats $(b p)=$ [fragment size (bp) - flanking regions (bp)]/ repeat size (bp). Repeat copy numbers were rounded down to the closest whole number. If the copy number was less than one, it was rounded to zero.

\section{Sequencing and phylogenetic analysis of Leptospiral strains}

PCR targeting the 16S rRNA gene was carried out for bacterial identification The following primers were used: 5'-GGCGGCGCGTCTTAAACATG-3' and 5'GTCCGCCTACGCACCCTTTACG-3'; these primers have the ability to amplify all pathogenic and non-pathogenic species of Leptospira sp. (Djadid et al., 2009). After verification of the amplicon by electrophoresis (in an ethidium bromide-containing 2\% agarose gel) and visualization upon UV light exposure, PCR products were purified using a commercial kit (Embiotech). The sample was sequenced at the Institute of Biotechnology, National Institute of Agricultura Technology (Argentina) using a 3130xl Genetic Analyzer (Applied Biosystems). For alignment and construction of the phylogeny, the program MEGA version 6.06 was used (Tamura et al., 2013). The dendogram basing in partial sequences of the 16S rRNA gene was constructed using Neighbour-joining with a bootstrap of 100 .

\section{Characterization of Aquaspirillum sp. isolates}

Real-time PCR amplification of the 16S rRNA gene was performed in a Rotor Gene Q thermocycler (Qiagen, Hilden, Germany) in a final volume of $20 \mu 1$ using EvaGreen as intercalating fluorescent dye (KAPA FAST, Biosystems, Woburn, USA). Generic primers p201 (5'-GAGGAAGGIGIGGAIGACGT-3') and p1370 (5'-AGICCCGIGAACGTATTCAC-3') were used (Tseng et al., 2003). Primers were synthesized at Operon (Huntsville, Alabama, USA). Different PCR amplification conditions were tested, by changing variables such as temperature of annealing, primer concentration, number of cycles, DNA concentration and final reaction volume, in order to produce suitable fluorescence levels for HRM analysis. During the validation process the PCR products were run on agarose gels to check the size of the amplicons. PCR amplifications were carried out in a Rotor Gene Q thermocycler (Qiagen, Hilden, Germany) in a final volume of 20 $\mu 1$ using EvaGreen as intercalating fluorescent dye (KAPA FAST, Biosystems, Woburn, USA). The selected cycling program consisted of an initial denaturation of 2 minutes at $95^{\circ} \mathrm{C}$, and 45 cycles of $94^{\circ} \mathrm{C} 10^{\prime \prime}, 60^{\circ} \mathrm{C} 15^{\prime \prime}$, and $72^{\circ} \mathrm{C} 15^{\prime \prime}$ $\mathrm{PCR}$ products were purified and sequenced.

\section{Bacterial strains and growth conditions}

The leptospiral and spirilla strains used in this study were isolated from water samples of Callvú Leovú stream during 2016 years. Bacterial cells in logarithmic phase $\left(1-2 \times 10^{8}\right.$ cells / ml) were cultured by quadruplicate in EMJH medium (liquid and semi-solid) and sterile stream water; all tubes were incubated at two temperatures ranges $\left(4-10^{\circ} \mathrm{C}\right.$ and $\left.28-30^{\circ} \mathrm{C}\right)$ during 20 weekend and the growth was monitored periodically using dark-field microscopy. To perform this experiment, three groups were formed: "a" (Leptospires alone: Leptospira spp strain lepto106), "b" (Spirilla alone: Aquaspirillum spp. strain aquas106), and "c" (Leptospira spp. strain lepto106 whit Aquaspirillum spp. strain aquas106 at equal concentrations).

The concentration considered optimal was standardized by direct microscopy dark field using Neubauer chamber.

\section{RESULTS AND DISCUSSION}

\section{Bacterial strains isolates}

During the period April-December 2016 six leptospiral strains and six spirilla strains were obtained. All leptospiral isolates (strain lepto104, strain lepto106, strain lepto109, strain lepto110, strain lepto113 and strain lepto114) were negative by Multiple-Locus Variable-number tandem repeats Analysis (MLVA), however, molecular identification by $16 \mathrm{~S}$ rRNA gene sequences verified that strain lepto106 (used in this experiment) were identified as non-pathogenic leptospires whit sequence similarities of $99 \%$ using Blast (results not shown), and closely related to the species L. yanagawae and L. meyeri. All spirilla bacteria isolates (strain aquas106, strain aquas108, strain aquas109, strain aquas110, strain aquas113 and strain aquas114) were identified as Aquaspirillum spp. by molecular identification by $16 \mathrm{~S}$ rRNA gene sequences.

In moment of waters samples recollection in Callvú Leovú stream, we register temperature and $\mathrm{pH}$; the results obtained can be seen in Table 1 .

Leptospires such as spirilla developed both in tubes incubated at $13^{\circ} \mathrm{C}$ and at 28 $30^{\circ} \mathrm{C}$. In a sample of water obtained in month of January only the growth of Aquaspirillum spp. was observed in media incubated at $13^{\circ} \mathrm{C}$. Generally, in all tubes first the presence of Aquaspirillum spp. (cells of 5-10 $\mu \mathrm{m}$ in length and less than $0.22 \mu \mathrm{m}$ of diameter characterized by the presence of 3-5 turns and a characteristic movement) was observed, and a few days later the leptospires appeared, characterized by their flexuous motility and morphology typical of the genus Leptospira spp. (cells of $10-20 \mu \mathrm{m}$ in length and less than $0.22 \mu \mathrm{m}$ of under dark field microscopy (Table 2). All strains isolation was maintained in liquid and semisolid EMJH media. diameter

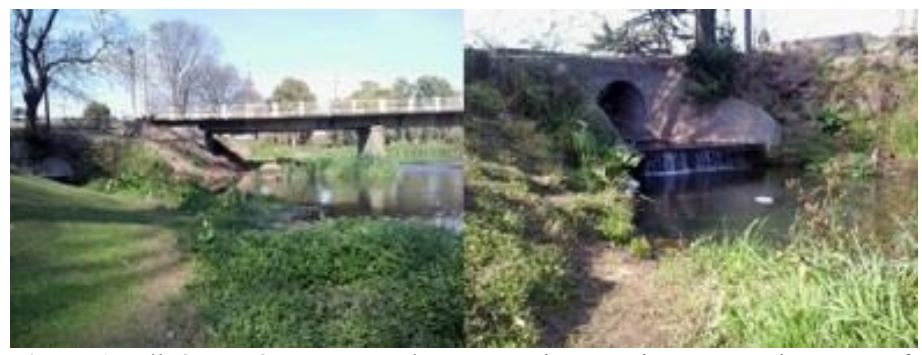

Figure 1 Callvú Leovú stream, Azul, Buenos Aires province, Argentina. Area of collection of water samples.

Table 1 Bacterial strains isolate from waters samples in Callvú Leovú stream, Azul, Buenos Aires province, Argentina.

\begin{tabular}{lcccccc}
\hline & \multicolumn{2}{c}{$\begin{array}{c}\text { Stream } \\
\text { water }\end{array}$} & \multicolumn{3}{c}{ Growth in EMJH medium (Days) } \\
\hline Months & $\mathbf{T}^{\mathbf{0}}$ & $\mathbf{p H}$ & $\begin{array}{c}\text { Leptospira } \\
\text { spp. }\end{array}$ & $\begin{array}{c}\text { Aquaspirillum } \\
\text { spp. }\end{array}$ & $\begin{array}{c}\text { Leptospira } \\
\text { spp. }\end{array}$ & $\begin{array}{c}\text { Aquaspirillu } \\
\text { m spp. }\end{array}$ \\
\hline April & 15 & 7.8 & 7 & 0 & 7 & 0 \\
\hline May & 12 & 7.8 & 7 & 0 & 8 & 6 \\
\hline June & 12 & 7.4 & 0 & 12 & 0 & 0 \\
\hline August & 14 & 7.7 & 10 & 8 & 6 & 4 \\
\hline September & 17 & 7.6 & 18 & 5 & 4 & 13 \\
\hline November & 16 & 8.6 & 14 & 7 & 7 & 4 \\
\hline December & 23 & 8.3 & 4 & 4 & 5 & 0 \\
\hline
\end{tabular}

Legend: $\mathrm{T}^{\mathrm{o}}$ - temperature

\section{Obtaining pure cultures of leptospiral and spirilla bacteria}

The EMJH media with the addition of $300 \mu \mathrm{g} / \mathrm{ml}$ of 5-fluorouracil were used to obtain the growth of leptospires in absence of spirilla bacteria. To obtain growth of spirilla bacteria in absence of leptospires, Thioglycollate media with addition 
of EMJH (10\%) and reverse were used. In Thioglycollate media (with 10\% EMJH medium) growth of Aquaspirillum spp. (3 x $10^{7}$ cells $/ \mathrm{ml}$ ) without the presence of leptospires, was observed on the second day of incubation at 28-30 $\mathrm{C}$; in this media biofilm-forming of Aquaspirillum spp. and changes in cell structure (length and number of spires increased) were found. Under these conditions they remained viable for more than 30 weeks. In EMJH medium (with 10\% Thioglycollate media) growth of Aquaspirillum spp. was observed during the second day of incubation at $28-30^{\circ} \mathrm{C}$; biofilmforming and changes in cell structure were not observed.

Table 2 Differential characteristics of leptospires and spirilla bacteria

\begin{tabular}{|c|c|c|}
\hline Phenotypic characteristic & $\begin{array}{l}\text { Leptospira spp. } \\
\text { strain lepto106 }\end{array}$ & $\begin{array}{c}\text { Aquaspirillum spp. } \\
\text { strain aquas106 }\end{array}$ \\
\hline Growth at $13^{\circ} \mathrm{C}$ & $\mathrm{X}$ & $\mathrm{X}$ \\
\hline Growth at $28-30^{\circ} \mathrm{C}$ & $\mathrm{X}$ & $\mathrm{X}$ \\
\hline Growth at $4-8^{\circ} \mathrm{C}$ & $\mathrm{X}$ & $\mathrm{X}$ \\
\hline Growth at $\mathrm{pH}<7.2$ & - & - \\
\hline 5-fluorouracil resistance & $\mathrm{X}$ & - \\
\hline Growth in EMJH medium & $\mathrm{X}$ & $\mathrm{X}$ \\
\hline $\begin{array}{l}\text { Growth in Thioglycollate } \\
\text { medium }\end{array}$ & - & $\mathrm{X}$ \\
\hline Helicoidally form & $\begin{array}{c}\text { Flexuous helical } \\
\text { cells }\end{array}$ & Rigid helical cells \\
\hline Cells dimensions & $\begin{array}{c}10-20 \mu \mathrm{m} \text { in length } \\
\text { and less than } 0.22 \\
\mu \mathrm{m} \text { of diameter }\end{array}$ & $\begin{array}{c}10-60 \mu \mathrm{m} \text { in length } \\
\text { and less than } 0.22 \\
\mu \mathrm{m} \text { of diameter }\end{array}$ \\
\hline Motility & By axial filaments & By polar flagellum \\
\hline
\end{tabular}

\section{Incubation and growth at $28-30^{\circ} \mathrm{C}$}

a) Leptospires alone (Leptospira spp. strain lepto106): In liquid EMJH medium leptospires reached their maximum development $\left(3 \times 10^{7}\right.$ cells $\left./ \mathrm{ml}\right)$ in the third week of incubation, and from the fourth to the seventh a plateau phase was observed with approximately $2.5 \times 10^{6}$ cells / $\mathrm{ml}$; then declined and viable cells were undetectable after 12 weeks of incubation (Figure 2A). In contrast, in semi-solid EMJH medium the maximum development $\left(2.5 \times 10^{6}\right.$ cells $\left./ \mathrm{ml}\right)$ was observed from the second week of incubation, and remained stable for up to 12 weeks (Figure 2B). In watercourse leptospires behaved similarly to those observed in liquid EMJH media (Figure 2C).

b) Spirilla alone (Aquaspirillum spp. strain aquas106): In liquid EMJH media spirilla bacteria showed a progressive growth, reaching $3 \times 10^{7}$ cells $/ \mathrm{ml}$ in the second week of incubation. In the first three weeks of incubation cells were observed to be larger with increase in the number of spires. After the third week spirilla bacteria remained viable for up to 12 weeks (Figure 2A). In semi-solid EMJH medium, Aquaspirillum spp. increased $3 \times 10^{7}$ cells / ml rapidly in the first week of incubation. From the seventh week Aquaspirillum spp. enter a plateau phase up to 12 weeks with approximately $2.5 \times 10^{6}$ cells / $\mathrm{ml}$ (Figure 2B); then in death phase cell mobility was not observed. In this fluid, during the first three weeks of incubation, changes in cellular structure (length and number of spires increased) were observed. In stream water Aquaspirillum spp. showed behaviour like that liquid EMJH media (Figure 2C).

c) Co-culture (Leptospira spp. strain lepto106 and Aquaspirillum spp. strain aquas106): in liquid EMJH medium both bacteria behaved in a similar way, increasing from $2.5 \times 10^{6}$ cells $/ \mathrm{ml}$ to nearly $5 \times 10^{6}$ cells $/ \mathrm{ml}$ during the first three weeks. Approximately $2.5 \times 10^{6}$ cells / ml, was constant for several weeks. In these medium small cells aggregates until week 14 were visible (Figure 4A); spirilla bacteria maintained mobility but changes in cellular structure (increase in length and number of turns) were observed. In semi-solid EMJH medium, leptospires increased to approximately $5 \times 10^{6}$ cells $/ \mathrm{ml}$ ) in the first week of incubation, however from the third week spirilla bacteria maintained similar cells concentrations (Figure 3B). In this media cellular aggregates on the surface of media were observed until the sixth week (Figure 4). In stream water Aquaspirillum spp. strain aquas106 growth more efficiently than EMJH media, increasing to $3 \times 10^{7}$ cells / $\mathrm{ml}$ in the first week up to week five of incubation. In this fluid leptospires growth similarly to that EMJH media (Figure 3C).
A

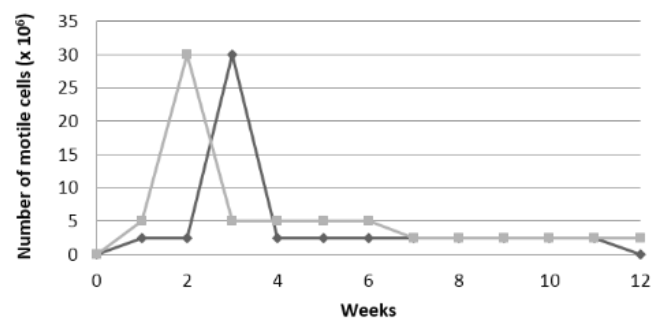

$\rightarrow-$ Leptospira spp.

Aquaspirillum spp.

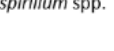

B

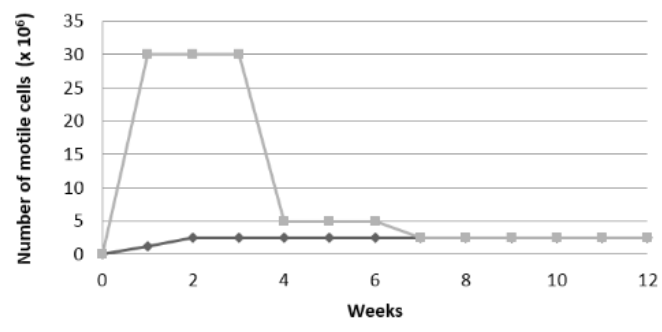

$\rightarrow$ Leptospira spp. - Aquaspirillum spp.

C

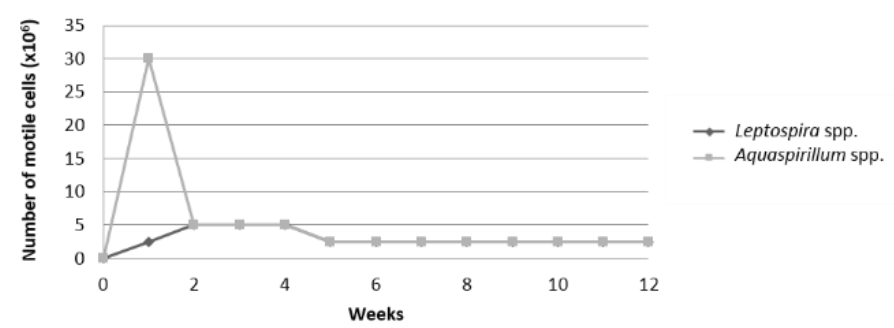

Figure 2 Development of Leptospira spp. strain lepto106 and Aquaspirillum spp. strain aquas106 alone in liquid EMJH medium (A), semi-solid EMJH medium (B) and stream water (C) incubated at $28-30^{\circ} \mathrm{C}$.

A
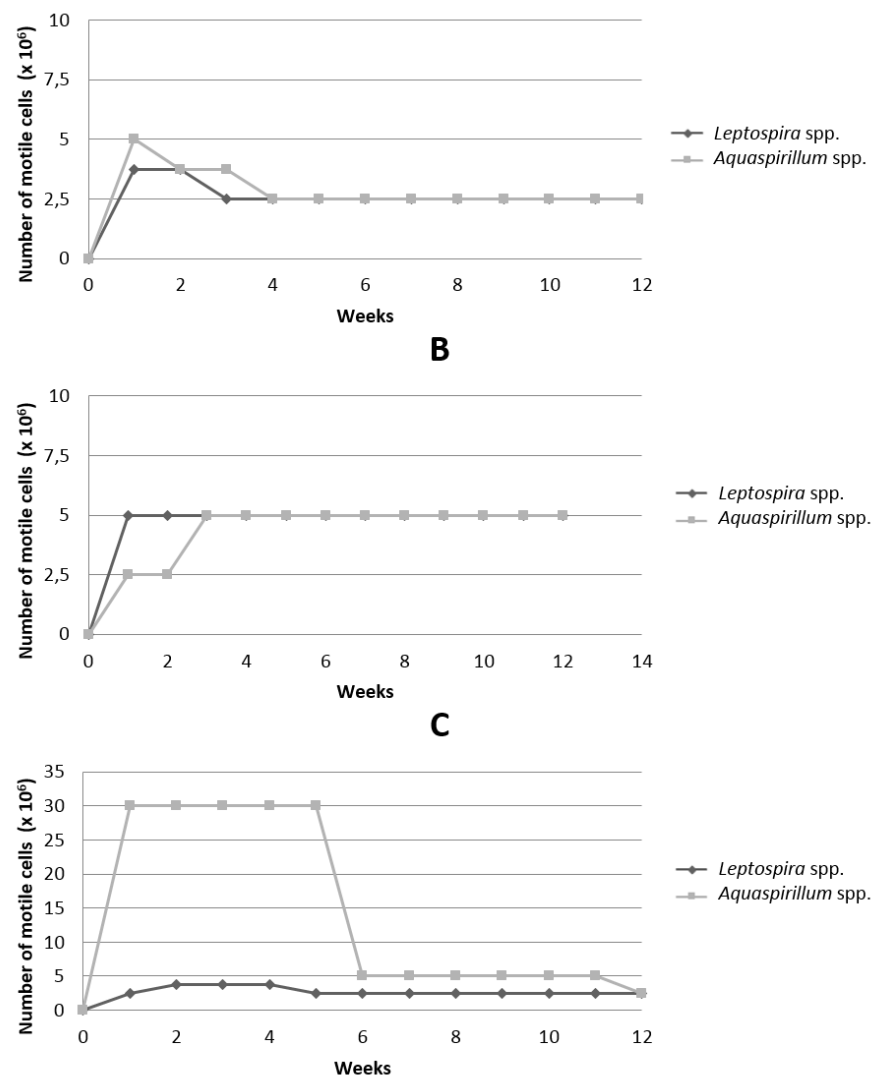

Figure 3 Co-culture of leptospires (Leptospira spp. strain lepto106) and spirilla (Aquaspirillum spp. strain aquas106) in liquid EMJH medium (A), semi-solid EMJH medium (B) and stream water (C) incubated at $28-30^{\circ} \mathrm{C}$. 


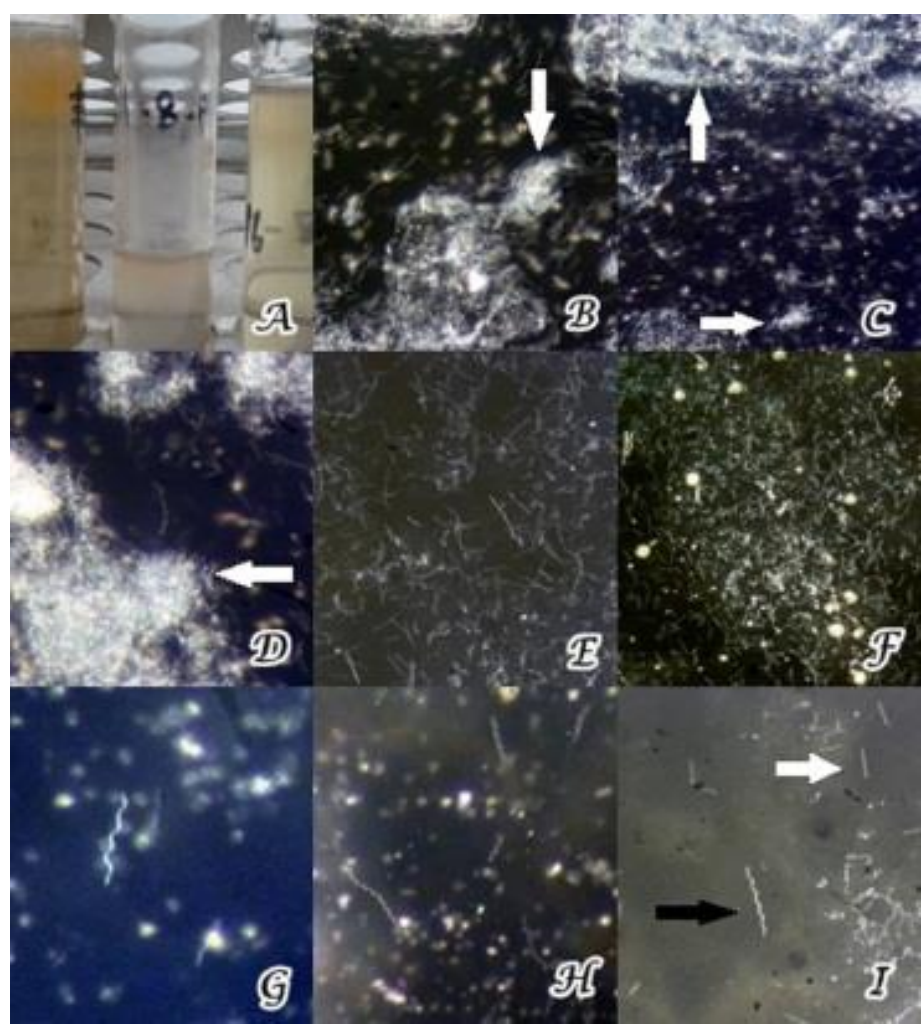

Figure 4 Cell aggregation and formation of biofilm between leptospires and Aquaspirillum spp. in semi-solid fluid incubated at $4^{\circ} \mathrm{C}$. (A) surface-attached biofilm in air-liquid interface. (B, C and D) aggregates between Leptospira spp. strain lepto106 and Aquaspirillum spp. strain aquas106 (white arrows) at 40x and 100x magnification. (E and F) dark field microscopy of spirilla bacteria and free leptospires in sectors with no cell aggregates at 100x and 40x magnification, respectively. ( $\mathrm{G}$ and $\mathrm{H}$ ) helical shape of Aquaspirillum spp. with variable number of spiras at 200x and 100x magnification, respectively. (I) leptospires (white arrows) and Aquaspirillum spp. (black arrows) at 100x magnification.

\section{Incubation and growth at $4-8^{\circ} \mathrm{C}$}

a) Leptospires alone (Leptospira spp. strain lepto106): leptospires developed at similarly in all media used. Although no significant development $\left(2.5 \times 10^{6}\right.$ cells $\left./ \mathrm{ml}\right)$ was observed; bacteria were viable and mobility after 12 weeks of incubation (Figure 5A, B and C). In liquid media leptospires increased their size, and even their hooks were more notorious under observation by dark field microscopy.

b) Spirilla alone (Aquaspirillum spp. strain aquas106): cells were undetectable in the first three weeks of incubation in all media used, however, when tubes were incubated at $28-30^{\circ} \mathrm{C}$ for one week, spirilla bacteria increased to approximately $3 \times 10^{7}$ cells $/ \mathrm{ml}$ (Figure 6A and B) and $5 \times 10^{6}$ cells $/ \mathrm{ml}$ (Figure 6C). In semi-solid EMJH media Aquaspirillum spp. strain aquas106 showed a more extensive stationary phase than liquid media, in addition cells with atypical mobility and shape were observed. No viable cells were seen after the eighth week in stream water media; however, in viscous media $2.5 \times 10^{6}$ cells $/ \mathrm{ml}$ were observed.

c) Co-culture (Leptospira spp. strain lepto106 and Aquaspirillum spp. strain aquas106): in liquid media (EMJH and stream water) no development was observed in the first 3 weeks, however, when tubes were incubated at $28-30^{\circ} \mathrm{C}$ for one week, spirilla $\left(3 \times 10^{7}\right.$ cells $\left./ \mathrm{ml}\right)$ and leptospires $\left(2.5 \times 10^{6}\right.$ cells $\left./ \mathrm{ml}\right)$ were observed (Figure 7A and C), remaining viable after 10 weeks in liquid EMJH medium. However, in stream water (after incubation at $\left.28-30^{\circ} \mathrm{C}\right) 2.5 \times 10^{6}$ leptospires $/ \mathrm{ml}$ and $5 \times 10^{6}$ spirilla $/ \mathrm{ml}$ were found, from the fifth week the number of cells / $\mathrm{ml}$ was reversed. In semi-solid EMJH media leptospires increased to $3 \times 10^{7}$ cells / $\mathrm{ml}$ and spirilla to $2.5 \times 10^{6}$ cells $/ \mathrm{ml}$ in the first week of incubation at $4-8^{\circ} \mathrm{C}$ (Figure $7 \mathrm{~B}$ ), this concentration was constant after 16 weeks of incubation. The formation of cellular aggregate between leptospires and spirilla bacteria was observed from the first week of incubation (Figure 4).
A
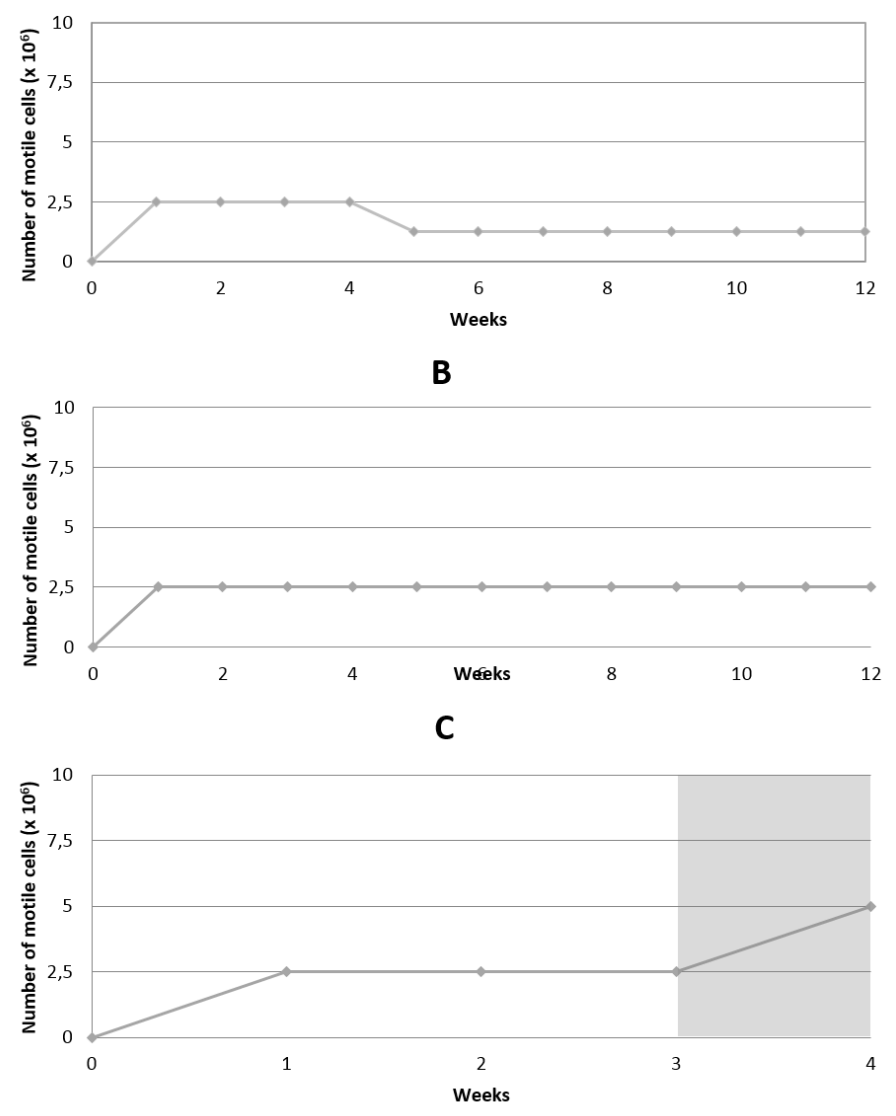

Figure 5 Development of Leptospira spp. strain lepto106 in liquid EMJH medium (A), semi-solid EMJH medium (B) and stream water (C) incubated at 4 $8^{\circ} \mathrm{C}$. In the grey column the period of incubation at $28-30^{\circ} \mathrm{C}$ is observed.

\section{$A$ and $B$}

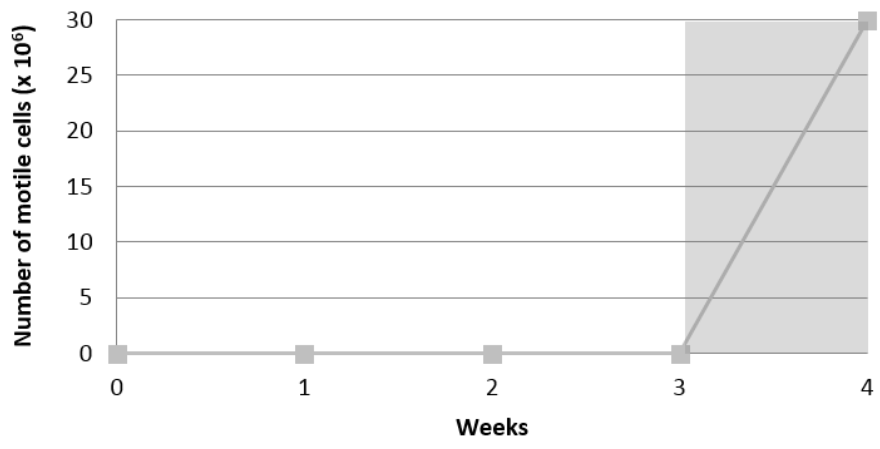

C

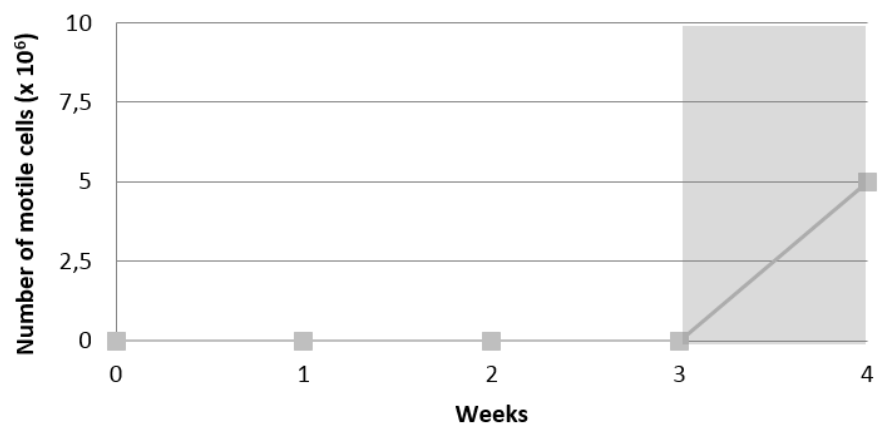

Figure 6 Development of Aquaspirillum spp. strain aquas106 in liquid EMJH medium (A), semi-solid EMJH medium (B) and stream water (C) incubated at 4$8^{\circ} \mathrm{C}$. In the grey column the period of incubation at $28-30^{\circ} \mathrm{C}$ is observed. 
A

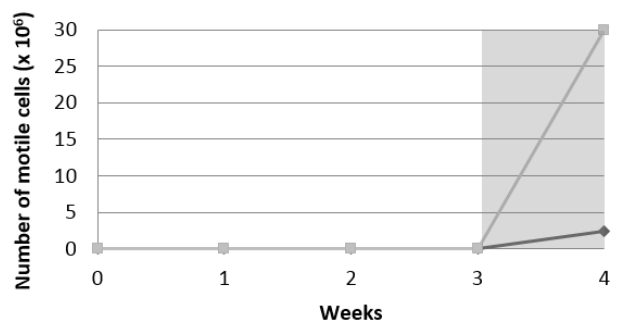

B

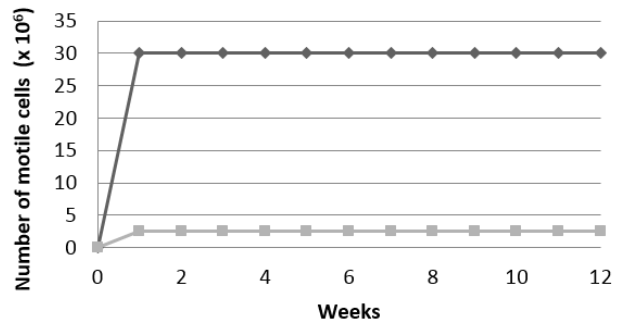

C

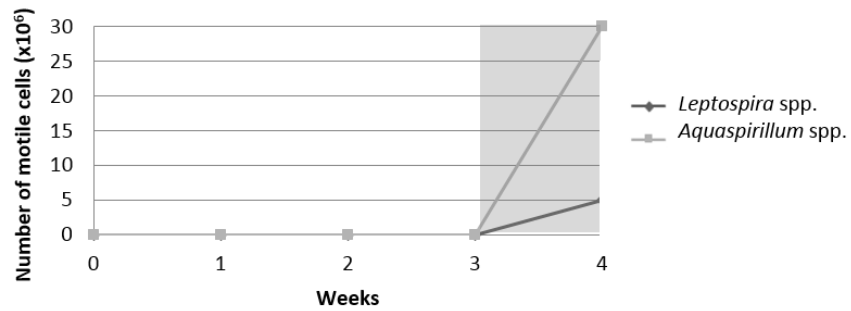

Figure 7 Co-culture of leptospires (Leptospira spp. strain lepto106) and spirilla (Aquaspirillum spp. strain aquas106) in liquid EMJH medium (A), semi-solid EMJH medium (B) and stream water (C) incubated at $4-8^{\circ} \mathrm{C}$. In the grey column the period of incubation at $28-30^{\circ} \mathrm{C}$ is observed.

In water samples from Callvú Leovú stream, spirilla and saprophytes leptospires were isolated; the growth in liquid EMJH media was on average of 4.6 days at $13^{\circ} \mathrm{C}$ and 6.9 days at $28-30^{\circ} \mathrm{C}$. The $\mathrm{pH}$ recorded in water samples was always above 7.2, being optimum for the growth of helical bacteria; in winter period the temperature of stream water was not lower than $11.5^{\circ} \mathrm{C}$, and did not inhibit the bacterial development in specific media. Ours results suggest the importance of 5-fluorouracil as specific antimicrobial when leptospires are to be isolated from surface water samples. Spirilla (Aquaspirillum spp.) they are rigid helical bacteria not retained by membranes filter whit a pore diameter size of $0.22 \mu \mathrm{m}$. These bacteria could be confused with leptospires at low magnification under dark field microscopy. The differential characteristics between Leptospira spp. and Aquaspirillum spp. are detailed in the table 2. The viability of leptospires and spirilla bacteria in all media used according to incubation temperature is detailed in the table 3 .

Table 3 Viability of the bacteria in the media used according to incubation temperature, using dark field microscopy

\begin{tabular}{lcccccc}
\hline & \multicolumn{2}{c}{ Leptospira spp. } & \multicolumn{2}{c}{$\begin{array}{c}\text { Aquaspirillum } \\
\text { spp. }\end{array}$} & \multicolumn{2}{c}{$\begin{array}{c}\text { Leptospira spp. + } \\
\text { Aquaspirillum } \\
\text { Mpp. }\end{array}$} \\
\cline { 2 - 7 } & $\mathbf{4 - 8}^{\circ} \mathbf{C}$ & $\begin{array}{c}\mathbf{2 8 - 3 0} \\
{ }^{\circ} \mathbf{C}\end{array}$ & $\mathbf{4 - 8}^{\circ} \mathbf{C}$ & $\begin{array}{c}\mathbf{2 8 - 3 0} \\
{ }^{\circ} \mathbf{C}\end{array}$ & $\mathbf{4 - 8}^{\circ} \mathbf{C}$ & $\begin{array}{c}\mathbf{2 8 - 3 0} \\
{ }^{\circ} \mathbf{C}\end{array}$ \\
\hline $\begin{array}{l}\text { Liquid } \\
\text { EMJH } \\
\text { medium }\end{array}$ & 168 & 84 & 77 & 84 & 140 & 98 \\
\hline $\begin{array}{l}\text { Semi-solid } \\
\text { EMJH } \\
\text { medium }\end{array}$ & 168 & 168 & 84 & 98 & 217 & 168 \\
\hline $\begin{array}{l}\text { Stream } \\
\text { water }\end{array}$ & 112 & 98 & 56 & 84 & 105 & 98 \\
\hline
\end{tabular}

In specific media for the isolation of leptospires as in stream water, spiral bacteria always reached a higher number of cells in the first week of incubation at $28-30^{\circ}$ $\mathrm{C}$ compared to leptospires. Spirilla bacteria was undetectable in the first three weeks of incubation at $4-8^{\circ} \mathrm{C}$ in all media used, however, in a face of thermal stimulus (incubation at $28-30^{\circ} \mathrm{C}$ for one week) cells increased to approximately 3 x $10^{7}$ cells $/ \mathrm{ml}$, and in semi-solid EMJH medium to remain viable after 12 weeks. Spirilla bacteria and leptospires were able to remain viable for three weeks at low temperatures until the environment conditions are optimal.

Leptospires developed in all media used and remained motile for 112 to 168 days (at $4-8^{\circ} \mathrm{C}$ of incubation) in stream water and liquid EMJH medium respectively; however semi-solid EMJH media was more efficient at $28-30^{\circ} \mathrm{C}$. These results are like those observed by Trueba $\boldsymbol{e t}$ al., (2004) who described the survival of leptospires for 110 days (aqueous media) and 347 days (semi-solid medium) in distilled water (Trueba et al., 2004). In liquid EMJH medium viable cells of leptospires were undetectable after 84 days of incubation at $28-30^{\circ} \mathrm{C}$, possibly by depleting nutrient medium.

Leptospires and spirilla bacteria (co-culture) growth in liquid EMJH media incubated at $28-30^{\circ} \mathrm{C}$, in this medium, Aquaspirillum spp. strain aquas106 maintained mobility for several weeks, although changes in cell structure (increase in length and number of turns) were observed. The co-culture in liquid media (EMJH and stream water) incubated at $4^{\circ} \mathrm{C}$, Aquaspirillum spp. strain aquas106 did not develop during three weeks. In semi-solid EMJH media, Leptospira spp. strain lepto106 showed more cell numbers / $\mathrm{ml}$ in the first week of incubation respect to Aquaspirillum spp. strain aquas106, and this concentration was constant after 16 weeks. In stream water Aquaspirillum spp. strain aquas106 showed more efficient growth than EMJH medium.

In semi-solid EMJH medium, cell aggregates between leptospires and spirilla bacteria were observed on the surface, which persisted up to the sixth week. Ristow et al., (2008) observed that $L$. interrogans serovar Lai strain Lai 56601 formed a halo attached to the wall of glass tubes at the air-liquid (Ristow et al., 2008).

Cell aggregation and formation of biofilm between Leptospira spp. strain lepto106 and Aquaspirillum spp. strain aquas106 was observed in semi-solid fluid incubated at $4^{\circ} \mathrm{C}$ as $28-30^{\circ} \mathrm{C}$. In our study, the formation of cellular aggregate between leptospires and spirilla bacteria was independent at incubation temperature. Other studies showed the ability of $L$. biflexa to form biofilm at three different temperatures (Ristow et al., 2008). Viscosity may favour the aggregation of leptospires by providing a matrix that holds the cells together, facilitating motility and therefore chemotaxis (Trueba $\boldsymbol{e t}$ al., 2004). Cel aggregation may be a mechanism that facilitates the adaptation of leptospires to different environmental conditions. Two types of biofilm architecture were observed by Ristow et al., (2008), one consisting of large, distinct mound-shaped microcolonies (L. interrogans) and the other showing smaller microcolonies with a flatter structure that were linked together by a complex network of $L$. biflexa (Ristow et al., 2008). This mechanism has been observed in saprophytic leptospires as well as in pathogens leptospires (Barragan et al., 2011; Brihuega at al., 2012; Ristow et al., 2008; Trueba et al., 2004).

\section{CONCLUSION}

In natural water sources there is a great diversity of environmental bacteria that could interact with the leptospires. This interaction has been with Sphingomonas consortium and Azospirillum brasilense (Barragan et al., 2011; Kumar et al., 2015). Leptospires and spirilla bacteria share similar habitats in nature, the presence of Aquaspirillum spp. in water would help to increase the average life of leptospiras in the environment. All isolates were negative by Multiple-Locus Variable-number tandem repeats Analysis (MLVA), however, molecular identification by $16 \mathrm{~S}$ rRNA gene sequences verified that all isolates were identified as non-pathogenic leptospires. Further studies will aim to meet serogroups circulating leptospires in surface waters.

\section{REFERENCES}

Barragan, V.A., Mejia, M. E., Trávez, A., Zapata, S., Hartskeerl, R. A., Haake, D. A., Trueba, G. A. (2011) Interactions of Leptospira with environmental bacteria from surface water. Current microbiology, 62 (6), 1802-06 https://doi.org/10.1007/s00284-011-9931-3

Bourhy, P., Collet, L., Brisse, S., Picardeau, M. (2014) Leptospira mayottensis sp. nov., a pathogenic species of the genus Leptospira sp. isolated from humans $\begin{array}{llllll}\text { Int } J \text { Syst Evol Microbiol, } 64 \text { (12), 4061-67. } & \end{array}$ https://dx.doi.org/10.1099/ijs.0.066597-0

Brihuega, B., Samartino, L., Auteri, C., Venzano, A., Caimi, K. (2012) In vivo cell aggregations of a recent swine biofilm-forming isolate of Leptospira interrogans strain from Argentina. Rev Argent Microbiol, 44: 138-143. http://www.scielo.org.ar/scielo.php?script=sci_arttext\&pid=S0325-

75412012000300002\&lng=es\&tlng $=$ en

Djadid, N. D., Ganji, Z. F., Gouya, M. M., Rezvani, M., Zakeri, S. (2009) A simple and rapid nested polymerase chain reaction-restriction fragment length polymorphism technique for differentiation of pathogenic and nonpathogenic Leptospira spp. Diagn Microbiol Infect Dis, 63 (3), 251-56. https://doi.org/10.1016/j.diagmicrobio.2008.10.017

Faine, S., Adler, B., Bolin, C., \& Perolat, P. (1999). Leptospira and Leptospirosis. 2 ed. Melbourne: MediSci, ISBN (print) $095863260 \mathrm{X}$

Kumar, K. V., Lall, C., Raj, R. V. (2015) Coexistence and survival of pathogenic leptospires by formation of biofilm with Azospirillum. FEMS Microbiol Ecol.; 91https://doi.org/10.1093/femsec/fiv051 
Majed Z, Bellenger E, Postic D, Pourcel C, Baranton G, Picardeau, M. (2005) Identification of variable-number tandem-repeat loci in Leptospira interrogans sensu stricto. Journal Clinical Microbiology 43: 539-45. http://doi.org/10.1128/JCM.43.2.539-545.2005

Pavan, M. E., Cairo, F., Pettinari, M. J., Samartino, L., Brihuega, B. (2011) Genotyping of Leptospira interrogans strains from Argentina by multiple-locus variable-number tandem repeat analysis (MLVA). Comp Immunol Microbiol Infect Dis, 34 (2), 135-41. https://doi.org/10.1016/j.cimid.2010.06.002

Picardeau, M. (2017). Virulence of the zoonotic agent of leptospirosis: still terra incognita?. Nature Reviews $\quad$ Microbiology, 15(5), 297. https://doi.org/10.1038/nrmicro.2017.5

Pot B., Gillis M., De LEY J. (2006) The Genus Aquaspirillum. In: Dworkin M.

Falkow S., Rosenberg E., Schleifer KH., Stackebrandt E. (eds) The Prokaryotes. Springer, New York, NY. https://doi.org/10.1007/0-387-30745-1_30

Ristow, P., Bourhy, P., Kerneis, S., Schmitt, C., Prevost, M. C., Lilenbaum, W., Picardeau, M. (2008) Biofilm formation by saprophytic and pathogenic $\begin{array}{llll}\text { leptospires. } & \text { Microbiology, 1309-17. }\end{array}$ https://doi.org/10.1099/mic.0.2007/014746-0

Tamura, K., Stecher, G., Peterson, D., Filipski, A., Kumar, S. (2013) MEGA6: molecular evolutionary genetics analysis version 6.0. Molecular biology and evolution, 30 (12), 2725-29. https://doi.org/10.1093/molbev/mst197

Trueba, G., Zapata, S., Madrid, K., Cullen, P., Haake, D. (2004) Cell aggregation: a mechanism of pathogenic Leptospira to survive in fresh water. Int Microbiol, 7, 35-40. https://www.ncbi.nlm.nih.gov/pubmed/15179605

Trueba, G., Zapata, S., Madrid, K., Penafiel, N. (2002) Adaptación de Leptospira interrogans (sensu stricto) al agua dulce. Rev Cubana Med Trop, 54 (1), 11-14. http://scielo.sld.cu/scielo.php?script=sci arttext\&pid=S0375-

07602002000100003\&lng=es\&tlng=es

Tseng, C. P., Cheng, J. C., Tseng, C. C., Wang, C., Chen, Y. L., Chiu, D. T.Y., Liao, H. C., Chang, S. S. (2003) Broad-range ribosomal RNA real-time PCR after removal of DNA from reagents: melting profiles for clinically important bacteria. Clin Chem, 49, 306-9. https://doi.org/10.1373/49.2.306 